\title{
The academic impact of online mathematics learning during COVID-19 for junior high school students
}

\section{Putu Wisna Ariawan}

Mathematics Education Study Program, Ganesha University of Education, Bali, Indonesia

* Correspondence: wisna.ariawan@undiksha.ac.id

(C) The Author 2022

\begin{abstract}
Until now, no research explicitly examines the academic impact on public junior high school students in Singaraja City. The actual condition of the academic impact of online mathematics learning is necessary to be revealed immediately. This information can be used as a basis for teachers designing and implementing mathematics learning to minimize or eliminate the negative impact of online learning. This study involved 507 public junior high school students distributed over four public schools in Singaraja City as the sample. This study used a questionnaire instrument consisting of 14 items, and the data were tabulated based on the responses entered on the google form. The study results showed that students experienced several academic impacts as a result of online learning of mathematics. The academic impacts that students most felt among others: the amount of mathematics material was hard to understand, students doubted the accountability of the grade obtained by their friends, decreased enthusiasm for learning, and students felt that their academic abilities were e not optimal. The conclusion obtained from this study is that online mathematics learning during COVID-19 had an academic impact on public junior high school students in Singaraja City.
\end{abstract}

Keywords: academic impact; COVID-19; mathematics; online learning 


\section{Introduction}

Today COVID-19 pandemic becomes an exciting focus to discuss because of the impact in all aspects of life, including education. The significant impact of the COVID-19 pandemic is feared to have a negative effect on the education world. It is understandable because there are changes in the learning process that are usually done face-to-face in class that must be done online by utilizing network-based technology. Therefore, all components involved in the implementation of learning, from schools, teachers, and students, must adapt to the implementation of online learning. Adaptations that teachers and students must make will undoubtedly cause various problems in learning (Alomyan, 2021; Yilmaz \& Kostur, 2021; Yohannes et al., 2021).

The COVID-19 pandemic is believed to have a massive impact on education. It led many studies being conducted in various countries to look at the impact of COVID-19 on learning, particularly related to online learning (Adnan, 2020; Al-Mawee et al., 2021; Chaturvedi et al., 2021; Chirinda et al., 2021; Mengistie, 2021; Mukuka et al., 2021; Noori, 2021; Uegatani et al., 2021; Upoalkpajor \& Upoalkpajor, 2020; Yilmaz \& Kostur, 2021). Research on the academic impact of online learning during COVID-19 has been carried out by Alomyan (2021) and BaltàSalvador et al. (2021). Both of these studies were conducted at a university outside Indonesia.

In Indonesia, many studies have been conducted that examine the impact of online learning, especially on students. These studies did not give the same results and sometimes showed contradictory results (Baltà-Salvador et al., 2021). Several research results showed that online learning positively impacted students' motivation and learning outcomes (Hasanah et al., 2020; Khurriyati et al., 2021; Mandailina et al., 2021; Safrawita, 2021; Wasiah, 2021; Yuliana, 2021). Meanwhile, several other research results showed the opposite result; namely, online learning had a negative impact on student motivation and learning outcomes (Basa \& Hudaidah, 2021; Fadilla et al., 2021; Mukuka et al., 2021; Noori, 2021; Sukma \& Priatna, 2021; Utami \& Cahyono, 2020; Wasiah, 2021; Yohannes et al., 2021; Yunitasari \& Hanifah, 2020).

In every learning, either carried out face-to-face or online, there will always be an interaction. According to Bernard et al. (2009), there are three types of interaction in the learning process: the interaction between students and students, students with teachers, and students with the material. The change from face-to-face learning to online learning will potentially change the quality of the three types of interaction. The type of interaction that is somewhat limited is the interaction between students and students (Fauzy \& Nurfauziah, 2021; Kalogeropoulos et al., 2021) and students and teachers (Thanji \& Vasantha, 2018). In online learning, discussions between students are very limited (Calder et al., 2021).

Changes in the three types of interactions can undoubtedly have an impact on students' interests, motivation, learning outcomes, and perceptions of online learning (Basa \& Hudaidah, 2021; Fadilla et al., 2021; Mukuka et al., 2021; Noori, 2021; Rivai et al., 2021; Sukma \& Priatna, 2021; Utami \& Cahyono, 2020; Wasiah, 2021; Yohannes et al., 2021; Yunitasari \& Hanifah, 2020). Merrill (2013) states that learning interactions can be enhanced if guided and reinforced by effective instructional strategies. It implies that the teacher plays an important role in improving the quality of the three types of interaction. If the teacher cannot manage online learning well, the quality of the three types of interaction will be difficult to achieve 
optimally. Adnan (2020) reported that $71.4 \%$ of respondents stated that online learning through virtual meetings was less motivating for learning than face-to-face learning in the classroom, $78.6 \%$ stated that face-to-face contact with the teacher was necessary for effective learning. Furthermore, the interaction change factor, Baber (2020) states, the variables of student motivation to participate in online classes, subject structure, facilitation, and teacher knowledge were significant determinants of student learning perceptions and student satisfaction with online learning.

Public Junior High School in Singaraja City also carries out online learning. Although based on research, there is a bad impact of online mathematics learning (Hasanah et al., 2020; Tyaningsih et al., 2021), but until now, there has been no research that explicitly examines the academic impact on Public Junior High School students in the city Singaraja. Currently, there is only one study conducted by Ardiyanti et al. (2020) that examines the evaluation of the online mathematics learning process during the Covid-19 period. This study did not target junior high school students but only high school students (SMA) in the city of Singaraja.

With inconsistency results of several studies (Basa \& Hudaidah, 2021; Fadilla et al., 2021; Hasanah et al., 2020; Khurriyati et al., 2021; Mandailina et al., 2021; Mukuka et al., 2021; Noori, 2021; Safrawita, 2021; Sukma \& Priatna, 2021; Utami \& Cahyono, 2020; Wasiah, 2021; Yohannes et al., 2021; Yuliana, 2021; Yunitasari \& Hanifah, 2020) take appropriate steps to ensure the quality of the process and results of mathematics learning is the online learning continue to be implemented. Therefore, the real condition of the various academic impacts of online learning on mathematics learning is important to be revealed immediately. The results of this study were expected to provide an actual illustration of the things experienced and felt by Public Junior High School students in the city of Singaraja while participating in online mathematics learning. This information can later be used as a basis for teachers designing and implementing mathematics learning to minimize or even eliminate the negative impact of online learning.

This research examines the various academic impacts felt by Public Junior High School students in Singaraja City in online mathematics learning during COVID-19. As reviewed by Alomyan (2021) and Baltà-Salvador et al. (2021), the academic impact is still very relevant to study because the impact may be felt by students at the junior high school level.

\section{Methods}

The population of this study was junior high school students of 4 public schools in Singaraja City, namely Public Junior High School 1 Singaraja, Public Junior High School 2 Singaraja, Public Junior High School 3 Singaraja, and Public Junior High School 6 Singaraja. This study involved 507 junior high school students at four public schools with the distribution: 132 students at Public Junior High School 1 Singaraja, 126 students at Public Junior High School 2 Singaraja, 125 students at Public Junior High School 6 Singaraja, and 124 students at Public Junior High School 6 Singaraja. At each school, seventh dan 8th-grade students were given a questionnaire link, and then students were asked to fill out the questionnaire. The respondent data were tabulated based on the questionnaires sent by the respondents on the google form. 
Furthermore, the data were analyzed descriptively to determine the level of respondent approval of the questionnaire items based on predetermined criteria.

This study used a questionnaire instrument consisting of 14 items. The questionnaire item contains statements related to online learning. Online learning referred to in this study was in the form of comprehensive learning activity that used various digital platforms (zoom, google classroom, google meet, and others) connected to the internet (such as smartphones, laptops, and others) to communicate directly or indirectly by online (Assidiqi \& Sumarni, 2020; Singh \& Thurman, 2019).

The complete questionnaire items are presented in Table 5. Each item used a 4-point Likert scale whose answers were strongly agreed, agree, disagree, and strongly disagree. The gradation of hesitation was not included so that the response obtained could give a clear direction of the trend. To determine the level of approval for each item, three levels of approval were used, namely high, medium, and low, using the formula developed by Alomyan (2021) as follows:

$$
\text { Scale range }=\frac{\text { maximal score }- \text { minimum score }}{\text { number of level }}
$$

Based on the formula (1), the level of approval for each item in the questionnaire can be calculated and presented as in Table 1 below.

Table 1. Item classification of the agreement level, adapted from Alomyan (2021)

\begin{tabular}{cc}
\hline Interval & Agreement Level \\
\hline $1-1.999$ & Low \\
$2-2.999$ & Medium \\
$3-4$ & High \\
\hline
\end{tabular}

Before the questionnaire was used, a questionnaire review process was carried out through professional judgment to see the validity of the contents of the questionnaire. Content validity testing was done by involving an expert in mathematics education and an assessment expert. Gregory formula was used to determine the validity of the contents of the questionnaire. Furthermore, to determine the internal validity of the questionnaire, a field trial was conducted involving 95 students of Public Junior High School 8 Singaraja. Its internal validity was seen based on the value of the Pearson correlation coefficient on each item of the questionnaire.

Meanwhile, the stability of the questionnaire was seen based on the value of the Cronbach Alpha coefficient obtained. The Pearson correlation coefficient and Cronbach Alpha coefficient were calculated using the IBM SPSS Statistics Version 20. To interpret the Pearson correlation coefficient, the following Table 2 criteria were used.

Table 2. General guidelines for interpreting validity coefficients (Saad et al., 1999)

\begin{tabular}{ll}
\hline Validity Coefficients Range & Interpretation \\
\hline Upper than 0.35 & very beneficial \\
$0.21-0.35$ & likely to be useful \\
$0.11-0.20$ & depends on circumstances \\
Lower than 0.11 & unlikely to be useful \\
\hline
\end{tabular}


Based on the criteria on Table 2 above, the item was considered valid and can be used if the Pearson correlation coefficient value was at least 0.21. To interpret the value of the Cronbach Alpha coefficient, the following Table 3 criteria were used.

Table 3. General guidelines for interpreting the reliability coefficient (Saad et al., 1999)

\begin{tabular}{ll}
\hline Reliability Coefficient Score & Interpretation \\
\hline Upper than 0.9 & excellent \\
$0.80-0.89$ & good \\
$0.70-0.79$ & adequate \\
Lower than 0.70 & may have limited applicability \\
\hline
\end{tabular}

Based on the criteria in Table 3, the questionnaire was considered reliable and can be used if the Cronbach Alpha coefficient value was at least 0.70 .

\section{Results}

From the results of the questionnaire test consisting of 14 items, the content validity coefficient value was 1.00. The internal validity of each questionnaire item is presented in Table 4 below.

Table 4. Pearson correlation value of each questionnaire

\begin{tabular}{ccc}
\hline $\begin{array}{c}\text { Item } \\
\text { Number }\end{array}$ & Coefficient Correlation & Interpretation \\
\hline 1 & $\left.0.608^{*}\right)$ & very beneficial \\
2 & $\left.0.621^{*}\right)$ & very beneficial \\
3 & $\left.0.499^{*}\right)$ & very beneficial \\
4 & $\left.0.482^{*}\right)$ & very beneficial \\
5 & $\left.0.616^{*}\right)$ & very beneficial \\
6 & $\left.0.635^{*}\right)$ & very beneficial \\
7 & $\left.0.547^{*}\right)$ & very beneficial \\
8 & $\left.0.543^{*}\right)$ & very beneficial \\
9 & $\left.0.571^{*}\right)$ & very beneficial \\
10 & $\left.0.448^{*}\right)$ & very beneficial \\
11 & $0.368^{*}$ & very beneficial \\
12 & $\left.0.622^{*}\right)$ & very beneficial \\
13 & $\left.0.429^{*}\right)$ & very beneficial \\
14 & $0.443^{*}$ & very beneficial \\
\hline
\end{tabular}

Description: *) significant for $\alpha=0.01$

From the results in Table 4, it can be concluded that the 14 items used were in a very beneficial category, so that they were suitable to be used as the instruments in this study. Meanwhile, the Cronbach Alpha Coefficient value obtained was 0.867, which was good. It indicates that the questionnaire instrument had a good level of stability, so it is suitable to be used as an instrument in this study. Student responses to each item in the questionnaire can be presented in Table 5 below. 
Table 5. Mean, standard deviation, agreement level, percentage of student responses

\begin{tabular}{|c|c|c|c|c|c|c|}
\hline \multirow[b]{2}{*}{$\begin{array}{c}\text { Item } \\
\text { Number }\end{array}$} & \multirow{2}{*}{ Statement } & \multirow{2}{*}{ Mean } & \multirow{2}{*}{ SD } & \multirow{2}{*}{$\begin{array}{c}\text { Agreement } \\
\text { Level }\end{array}$} & \multicolumn{2}{|c|}{$\begin{array}{c}\text { Response } \\
\text { Percentage }\end{array}$} \\
\hline & & & & & $\begin{array}{l}\text { Agree- } \\
\text { Strongly } \\
\text { Agree } \\
\end{array}$ & $\begin{array}{l}\text { Disagree- } \\
\text { Strongly } \\
\text { Disagree } \\
\end{array}$ \\
\hline 1 & $\begin{array}{l}\text { I feel that the math scores } \\
\text { I get during online } \\
\text { learning do not fully } \\
\text { reflect the real math skills }\end{array}$ & 3.036 & 0.917 & High & $71.99 \%$ & $28.01 \%$ \\
\hline 2 & $\begin{array}{l}\text { I prefer to get math } \\
\text { lessons in person in class } \\
\text { than online }\end{array}$ & 3.276 & 0.789 & High & $87.97 \%$ & $12.03 \%$ \\
\hline 3 & $\begin{array}{l}\text { A lot of math material } \\
\text { that I do not understand } \\
\text { because math lessons are } \\
\text { done online }\end{array}$ & 3.294 & 0.814 & High & $88.36 \%$ & $11.64 \%$ \\
\hline 4 & $\begin{array}{l}\text { I am lazy to ask the } \\
\text { teacher because math } \\
\text { lessons are done online } \\
\text { even though I do not } \\
\text { understand the material }\end{array}$ & 3.028 & 0.795 & High & $76.53 \%$ & $23.47 \%$ \\
\hline 5 & $\begin{array}{l}\text { I often cannot take math } \\
\text { lessons online properly } \\
\text { due to internet network } \\
\text { problems }\end{array}$ & 2.477 & 0.844 & Medium & $47.53 \%$ & $52.47 \%$ \\
\hline 6 & $\begin{array}{l}\text { I often cannot take math } \\
\text { lessons online because I } \\
\text { do not have a quota }\end{array}$ & 1.730 & 0.662 & Low & $6.11 \%$ & $93.89 \%$ \\
\hline 7 & $\begin{array}{l}\text { As long as mathematics } \\
\text { learning is done online I } \\
\text { do not believe that the } \\
\text { math scores that my } \\
\text { friends get are purely } \\
\text { because of their abilities }\end{array}$ & 3.118 & 0.715 & High & $82.05 \%$ & $17.95 \%$ \\
\hline 8 & $\begin{array}{l}\text { I am often late in } \\
\text { submitting assignments } \\
\text { given by the teacher } \\
\text { because mathematics } \\
\text { learning is done online }\end{array}$ & 2.371 & 0.858 & Medium & $44.38 \%$ & $55.62 \%$ \\
\hline 9 & $\begin{array}{l}\text { Online Mathematics } \\
\text { learning makes my } \\
\text { enthusiasm for learning } \\
\text { decrease }\end{array}$ & 3.101 & 0.834 & High & $77.32 \%$ & $22.68 \%$ \\
\hline 10 & $\begin{array}{l}\text { I hope that math learning } \\
\text { will still be done online }\end{array}$ & 1.811 & 0.817 & Low & $18.15 \%$ & $81.85 \%$ \\
\hline 11 & $\begin{array}{l}\text { I often get good math } \\
\text { scores even though the } \\
\text { lessons are done online }\end{array}$ & 1.890 & 0.824 & Low & $21.50 \%$ & $78.50 \%$ \\
\hline
\end{tabular}


The academic impact of online mathematics learning during COVID-19 ...

\begin{tabular}{clccccc}
\hline $\begin{array}{c}\text { Item } \\
\text { Number }\end{array}$ & \multicolumn{1}{c}{ Statement } & Mean & SD & $\begin{array}{c}\text { Agreement } \\
\text { Level }\end{array}$ & $\begin{array}{c}\text { Response } \\
\text { Percentage } \\
\text { Agree- } \\
\text { Strongly } \\
\text { Disagree- } \\
\text { Agree }\end{array}$ & $\begin{array}{c}\text { Strongly } \\
\text { Disagree }\end{array}$ \\
\hline 12 & $\begin{array}{l}\text { When I am given a math } \\
\text { assignment, my parents } \\
\text { often help me when I do } \\
\text { the task }\end{array}$ & 2.162 & 0.813 & Medium & $34.91 \%$ & $65.09 \%$ \\
\hline 13 & $\begin{array}{l}\text { When given a test I often } \\
\text { look for answers in books } \\
\text { or the internet }\end{array}$ & 3.036 & 0.732 & High & $78.90 \%$ & $21.10 \%$ \\
\hline 14 & $\begin{array}{l}\text { Online learning causes } \\
\text { my math skills to decline }\end{array}$ & 3.122 & 0.832 & High & $78.30 \%$ & $21.70 \%$ \\
\hline
\end{tabular}

Based on the results obtained in Table 5, there were eight items with high agreement levels, three items in the medium category, and three items in the low category. The items with a high and medium level of agreement were items from statements related to the negative impact of online learning. Meanwhile, the items with low agreement levels were from two items which are statements related to the positive impact of online learning, and one item is a statement related to the negative impact of online learning.

Number 3 statement, "A lot of math material that I do not understand due to online learning," had the highest mean of 3.294 with the high agreement level. When viewed from the percentage, as many as $88.36 \%$ of respondents stated they agree or strongly agree with this statement.

Number 6 statement "I cannot attend math online learning due to no data package" had the lowest mean of 1.730 with the low agreement. Viewed from the percentage, only $6.11 \%$ of respondents stated agree or strongly agreed with this statement. It means only $6.11 \%$ of students could not attend online math lessons because they did not have a data package.

\section{Discussion}

Online learning has a psychological impact on students. Many students experience boredom in answering questions, so they finish it carelessly (Basa \& Hudaidah, 2021). The lack of seriousness in answering the questions is an indication that students have not used their abilities optimally in answering questions, so the results obtained do not actually show the optimal abilities of students. With this condition, students naturally feel that the math scores they achieve do not fully reflect their actual mathematical abilities.

Carrying out face-to-face mathematics learning means that they need the role of the teacher directly in learning. Mathematics learning conducted online will certainly reduce students opportunities to learn mathematics with their peers (Kalogeropoulos et al., 2021) because the interactions that occur between students are limited (Calder et al., 2021) and also the lack of interaction between students and teachers (Fauzy \& Nurfauziah, 2021). Students need the direct role of the teacher in learning so that students will feel more comfortable and feel that they receive direct guidance and direction from the teacher in studying the material. It 
may be why direct learning in class is more desirable for students than online learning. It is also the reason for students not expecting online mathematics learning.

Mathematics, as the subject of online learning, requires much preparation that must be done by the teacher so that the material presented can be easily understood by students (Yohannes et al., 2021). However, the effort is not enough because the decreasing pattern of interaction in online learning can make it difficult for students to understand the material (Budiman, 2021). Students can also not fully understand the material due to the limited communication that occurs with the teacher during online learning. Moreover, when mathematics learning does not require visualization, students will have difficulty understanding the material if the teacher cannot provide visualization directly (Basa \& Hudaidah, 2021). In addition, the motivational factor possessed by students is one of the determining variables on students in mastering the material (Safarati, 2021). With much material that students do not master, it will certainly impact students' academic abilities. It is the reason for students disagreement with the statement, "I often get good math scores even though the lessons conducted online".

Internet connection and the quality of learning influence students' motivation or enthusiasm to take part in online learning (Yanti \& Sumianto, 2021). Unstable internet connection becomes an obstacle in online learning (Amalia \& Sa'adah, 2020; Fauzy \& Nurfauziah, 2021; Nur, 2021). It impacts the number of students who often cannot take online math lessons well. The internet network that is often disrupted and the teacher's implementation of poorly designed learning may cause students to be less enthusiastic in participating in online learning. The results of this study are in line with the results of Adnan (2020) but contradict the results of his research by Safarati (2021), who reported that online learning caused $80.75 \%$ of students to feel enthusiastic about participating in learning. The poor quality of the internet network and the low quality of learning designed by the teacher will also have an impact on the low participation of students in participating in learning (Hutagaol, 2021) so that even though there is a material that has not been understood, students are reluctant to ask the teacher.

Related to the student delays in submitting assignments, one of the causes is internet interference. The existence of internet interference also impacts the student participation level in learning. Frequent internet interferences experienced by students will reduce interest in learning, resulting in decreased student participation in learning, for instance, the low number of student participation in collecting assignments (Budiman, 2021). The results of this study are in line with the findings of Majid et al. (2020), who reported the obstacles that are often faced during online learning, including students who are less disciplined in complying with the task collection schedule so that some students are late in collecting assignments. This result contrasts with Hidayati and Adilaturrahmah (2021), who found that $96 \%$ of students often submit the assignments on time.

The issue of academic cheating has the potential to occur during online learning. Issues of academic cheating that occur during online learning include the participation and dominance of parents doing their children assignments (Indrayani, 2021; Sapardan, 2021), children who search answers from search engines during the test (Indrayani, 2021; Sapardan, 2021; Putri et al., 2020). Another impact of online learning is piracy and plagiarism (Thanji \& Vasantha, 
2018). The potential for cheating can be caused by three factors: the quality of the questions or assignments, the attitude of the parents, and the students' integrity (Indrayani, 2021). Various potentials of cheating may occur during online learning will give students confidence that they lack confidence in the value of mathematics obtained by their friends purely because of their abilities. It is very natural for students to feel this way because conditions like this do not only happen to students of public junior high school in Singaraja city but can also happen in other areas or even in developed countries. Kuhfeld et al. (2020) report on the impact of COVID-19 on students in America. In almost all grades, the gains in students' math grades in fall 2020 were lower than the previous years. It can happen due to online learning that has not been able to maximize student knowledge compared to face-to-face learning (Nur, 2021) or the limited communication that occurs with teachers during online learning (Budiman, 2021).

\section{Conclusion}

This study showed several academic impacts felt by public junior high school students in Singaraja City in mathematics online learning during COVID-19. Students' academic impact is mostly felt related to their mathematical academic ability. Various potential frauds that can occur in the implementation of online mathematics learning cause students to feel their academic abilities are not optimal and doubt the academic abilities of their friends. The limitation of this study is that the conclusions obtained are very dependent on the sample responses used because each respondent subject will have different perceptions of the questionnaire items given. Based on these findings, if the learning is carried out online, it is expected that the mathematics teachers of public junior high schools in Singaraja should design and implement online learning properly that will be able to minimize and even eliminate the academic impact felt by public junior high school students in the city of Singaraja in participating in mathematics online learning.

\section{Conflicts of Interest}

The author guarantees that this article is the author's original. There is no conflict of interest in the publication of this manuscript. In addition, the author also guarantees that there are no issues that violate publication ethics such as plagiarism, misconduct, data forgery and/or tampering, and that this article has not been published or considered for publication in other places. Issues of originality and publication ethics are entirely the responsibility of the author.

\section{References}

Adnan, M. (2020). Online learning amid the COVID-19 pandemic: Students perspectives. Journal of Pedagogical Sociology and Psychology, 1(2), 45-51. https://doi.org/10.33902/JPSP.2020261309

Al-Mawee, W., Kwayu, K. M., \& Gharaibeh, T. (2021). Student's perspective on distance learning during COVID-19 pandemic: A case study of Western Michigan University, United States. International Journal of Educational Research Open, 2-2, Article 100080. 
https://doi.org/10.1016/j.ijedro.2021.100080

Alomyan, H. (2021). The impact of distance learning on the psychology and learning of university students during the COVID-19 pandemic. International Journal of Instruction, 14(4), 585-606. https://doi.org/10.29333/iji.2021.14434a

Amalia, A., \& Sa'adah, N. (2020). Dampak wabah COVID-19 terhadap kegiatan belajar mengajar di Indonesia [The impact of the COVID-19 outbreak on teaching and learning activities in Indonesia]. Jurnal Psikologi, 13(2), 214-225. https://doi.org/10.35760/psi.2020.v13i2.3572

Ardiyanti, N. M. D., Mahayukti, G. A., \& Sugiarta, I. M. (2020). Evaluasi proses pembelajaran matematika secara daring di SMAN Kota Singaraja [Evaluation of the online mathematics learning process at Singaraja City Senior High School]. Jurnal IKA, 18(2), $136-157$.

Assidiqi, M. H., \& Sumarni, W. (2020). Pemanfaatan platform digital di masa pandemi COVID-19 [Utilizing digital platforms during the COVID-19 pandemic]. Prosiding Seminar Nasional Pascasarjana, 298-303. https://proceeding.unnes.ac.id/index.php/snpasca/article/download/601/519

Baber, H. (2020). Determinants of students' perceived learning outcome and satisfaction in online learning during the pandemic of COVID-19. Journal of Education and E-Learning Research, 7(3), 285-292. https://doi.org/10.20448/journal.509.2020.73.285.292

Baltà-Salvador, R., Olmedo-Torre, N., Peña, M., \& Renta-Davids, A. I. (2021). Academic and emotional effects of online learning during the COVID-19 pandemic on engineering students. Education and Information Technologies, 26(6), 7407-7434. https://doi.org/10.1007/s10639-021-10593-1

Basa, Z. A., \& Hudaidah, H. (2021). Perkembangan pembelajaran daring terhadap minat belajar matematika siswa SMP pada masa pandemi COVID-19 [The development of online learning on interest in learning mathematics for junior high school students during the COVID-19 pandemic]. Edukatif: Jurnal Ilmu Pendidikan, 3(3), 943-950. https://doi.org/10.31004/edukatif.v3i3.461

Bernard, R. M., Abrami, P. C., Borokhovski, E., Wade, C. A., Tamim, R. M., Surkes, M. A., \& Bethel, E. C. (2009). A meta-analysis of three types of interaction treatments in distance education. Review of Educational Research, 79(3), 1243-1289. https://doi.org/10.3102/0034654309333844

Budiman, J. (2021). Evaluasi Pelaksanaan Pembelajaran daring di Indonesia selama masa pandemi COVID-19 [Evaluation of the Implementation of Online Learning in Indonesia during the COVID-19 pandemic]. VOX EDUKASI: Jurnal Ilmiah Ilmu Pendidikan, 12(1), 104-113. https://doi.org/10.31932/ve.v12i1.1074

Calder, N., Jafri, M., \& Guo, L. (2021). Mathematics education students' experiences during lockdown: Managing collaboration in elearning. Education Sciences, 11(4), 1-16, Article 191. https://doi.org/10.3390/educsci11040191

Chaturvedi, K., Vishwakarma, D. K., \& Singh, N. (2021). COVID-19 and its impact on education, social life and mental health of students: A survey. Children and Youth Services Review, 121, 105866. https://doi.org/10.1016/j.childyouth.2020.105866

Chirinda, B., Ndlovu, M., \& Spangenberg, E. (2021). Teaching mathematics during the COVID-19 lockdown in a context of historical disadvantage. Education Sciences, 11(4), 1-14, Article 177. https://doi.org/10.3390/educsci11040177

Fadilla, A. N., Relawati, A. S., \& Ratnaningsih, N. (2021). Jurnal Jendela Pendidikan, 1(2), $48-60$.

Fauzy, A., \& Nurfauziah, P. (2021). Kesulitan pembelajaran daring matematika pada masa pandemi COVID-19 di SMP Muslimin Cililin [Difficulties in learning mathematics online during the COVID-19 pandemic at SMP Muslimin Cililin]. Jurnal Cendekia: 
The academic impact of online mathematics learning during COVID-19 ...

Jurnal Pendidikan Matematika, 5(1), 551-561. https://doi.org/10.31004/cendekia.v5i1.514

Hasanah, R., Khaulah, S., \& Husnidar. (2020). Efektivitas pembelajaran daring pada mata pelajaran matematika selama pandemi COVID-19 di SMP Negeri 6 Samalanga [The effectiveness of online learning in mathematics during the COVID-19 pandemic at SMP Negeri 6 Samalanga]. ASIMETRIS: Jurnal Pendidikan Matematika dan Sains, 1(2), 8286. https://doi.org/10.34312/jmathedu.v2i2.11105

Hidayati, F. H., \& Adilaturrahmah, F. (2021). Students' dicipline in mathematics learning during COVID-19 pandemic. Journal of Medives: Journal of Mathematics Education IKIP Veteran Semarang, 5(2), 391-401. https://doi.org/10.31331/medivesveteran.v5i2.1726

Hutagaol, A. S. R. (2021). Analisis kesulitan guru matematika kelas VII dalam menerapkan pembelajaran daring selama pandemi COVID-19 di SMP Nusantara Indah [Analysis of the difficulties of grade VII mathematics teachers in implementing online learning during the COVID-19 pandemic at SMP Nusantara Indah]. Jurnal Riset Pendidikan Matematika Jakarta, 3(2), 16-22. https://doi.org/10.21009/jrpmj.v3i2.22121

Indrayani, S. (2021). Kejujuran, sebuah PR pendidikan di masa pandemi [Honesty, an educational homework during a pandemic]. Kompasiana, 1. https://www.kompasiana.com/selviaindrayani6341/60baf416d541df1cec6c6412/kejujur an-sebuah-pr-pendidikan-di-masa-pandemi

Kalogeropoulos, P., Roche, A., Russo, J., Vats, S., \& Russo, T. (2021). Learning mathematics from home during COVID-19: Insights from two inquiry-focussed primary schools. Eurasia Journal of Mathematics, Science and Technology Education, 17(5), 1-16. https://doi.org/10.29333/ejmste/10830

Khurriyati, Y., Setiawan, F., \& Mirnawati, L. B. (2021). Dampak pembelajaran daring terhadap hasil belajar siswa MI Muhammadiyah 5 Surabaya [The impact of online learning on student learning outcomes at MI Muhammadiyah 5 Surabaya]. Jurnal Ilmiah Pendidikan Dasar, 8(1), 91-104. https://doi.org/10.30659/pendas.8.1.91-104

Kuhfeld, M., Tarasawa, B., Johnson, A., Ruzek, E., \& Lewis, K. (2020). Learning during COVID-19: Initial findings on students ' reading and math achievement and growth. NWEA Research, November, 1-12. https://www.nwea.org/content/uploads/2020/11/Collaborative-brief-Learning-duringCOVID-19.NOV2020.pdf

Majid, F. A., Muya, B., Hestiningrum, E., \& Nugraha, A. (2020). Kedisiplinan belajar peserta didik dalam pembelajaran jarak jauh (study from home) pada masa darurat COVID-19 di SMP Muhammadiyah 9 Yogyakarta tahun ajaran 2019/2020 [Student learning discipline in distance learning (study from home) during the COVID-19 emergency at SMP Muhammadiyah 9 Yogyakarta for the 2019/2020 school year]. Journal of Chemical Information and Modeling, 1(1), 1689-1699.

Mandailina, V., Syaharuddin, S., Pramita, D., Ibrahim, I., \& Haifaturrahmah, H. (2021). Pembelajaran daring dalam meningkatkan motivasi dan hasil belajar peserta didik selama pandemi COVID-19: Sebuah meta-analisis [Online learning in improving students' motivation and learning outcomes during the COVID-19 pandemic: A meta-analysis]. Indonesian Journal of Educational Science (IJES), 3(2), 120-129. https://doi.org/10.31605/ijes.v3i2.955

Mengistie, T. A. (2021). Higher education students' learning in COVID-19 pandemic period: The Ethiopian context. Research in Globalization, 3, Article 100059. https://doi.org/10.1016/i.resglo.2021.100059

Merrill, M. D. (2013). First principles of instruction: Assessing and designing effective, efficient, and engaging. Pfeiffer. 
Mukuka, A., Shumba, O., \& Mulenga, H. M. (2021). Students' experiences with remote learning during the COVID-19 school closure: implications for mathematics education. Heliyon, 7(7), Article e07523. https://doi.org/10.1016/j.heliyon.2021.e07523

Noori, A. Q. (2021). The impact of COVID-19 pandemic on students' learning in higher education in Afghanistan. Heliyon, 7(10), Article e08113. https://doi.org/10.1016/j.heliyon.2021.e08113

Nur, A. S. (2021). Potret pembelajaran matematika pada masa pandemi: Tantangan dan peluang [Portraits of learning mathematics during a pandemic: Challenges and opportunities]. Jurnal Pendidikan Matematika, 4(1), 27-35. https://doi.org/10.30598/jupitekvol4iss1pp27-35

Rivai, M., Yusri, Tenri, A. R., \& Anwar, M. (2021). Teachers' language politeness, students' academic motivation and self-efficacy during school from home. Cypriot Journal of Educational. 16(5), 2161-2172. https://doi.org/10.18844/cjes.v16i5.6236

Saad, S., Carter, G. W., Rothenberg, M., \& Israelson. (1999). Testing and training administraton. 6. https://wdr.doleta.gov/directives/attach/TEN/ten2007/TEN21-07a1.pdf

Safarati, R. N. (2021). Dampak pembelajaran daring terhadap motivasi [Impact of online learning on motivation]. Genta Mulia, XII(1), 113-118.

Safrawita. (2021). Meningkatkan hasil dan motivasi belajar siswa pada pembelajaran daring dengan Google Classroom pada materi termokimia di kelas XI IPA semester ganjil SMA Negeri 2 Tanjungpinang [Improving student learning outcomes and motivation in online learning with Google Classroom on thermochemical material in class XI IPA odd semester SMA Negeri 2 Tanjungpinang]. Zarah, 9(1), 36-41.

Sapardan, D. A. (2021). Penguatan integritas siswa saat pandemi COVID-19 [Strengthening student integrity during the COVID-19 pandemic]. http://disdikkbb.org/news/penguatanintegritas-siswa-saat-pandemi-covid-19/

Singh, V., \& Thurman, A. (2019). How many ways can we define online learning? A systematic literature review of definitions of online learning (1988-2018). American Journal of Distance Education, 3(4), 289-306. https://doi.org/10.1080/08923647.2019.1663082

Sukma, Y., \& Priatna, N. (2021). Mathematics teachers' response to online learning during the COVID-19 pandemic: Challenges and opportunities. Kalamatika: Jurnal Pendidikan Matematika, 6(1), 1-14. https://doi.org/10.22236/KALAMATIKA.vol6no1.2021pp1-14

Thanji, M., \& Vasantha, S. (2018). A Study of benefits and limitations of e-learning - A learner's perspective. International Journal of Pure and Applied Mathematics, 118(5), 175-184. https://acadpubl.eu/jsi/2018-118-5/articles/5/13.pdf

Tyaningsih, R. Y., Arjudin, Prayitno, S., Jatmiko, \& Handayani, A. D. (2021). The impact of the COVID-19 pandemic on mathematics learning in higher education during learning from home (LFH): Students' views for the new normal. Journal of Physics: Conference Series, 1806(1), Article 012119. https://doi.org/10.1088/1742-6596/1806/1/012119

Uegatani, Y., Nakawa, N., \& Kosaka, M. (2021). Changes to tenth-grade Japanese Students' identities in mathematics learning during the COVID-19 pandemic. International Electronic Journal of Mathematics Education, 16(2), Article em0638. https://doi.org/10.29333/iejme/10905

Upoalkpajor, J.-L. N., \& Upoalkpajor, C. B. (2020). The impact of COVID-19 on education in Ghana. Asian Journal of Education and Social Studies, 9(1), 23-33. https://doi.org/10.9734/ajess/2020/v9i130238

Utami, Y. P., \& Cahyono, D. A. D. (2020). Study at home: Analisis kesulitan belajar matematika pada proses pembelajaran daring [Study at home: Analysis of learning difficulties in mathematics in the online learning process]. Jurnal Ilmiah Matematika Realistik, 1(1), 20-26. https://doi.org/10.33365/ji-mr.v1i1.252

Wasiah, U. (2021). Analisis kesulitan belajar matematika siswa SMP dalam pembelajaran 
daring pada masa pandemi COVID-19 [Analysis of the difficulty of learning mathematics for junior high school students in online learning during the COVID-19 pandemic]. $\begin{array}{lllll}\text { Jurnal Pendidikan } & \text { Matematika, } & 9(3), & 307 & \end{array}$ https://doi.org/10.23960/mtk/v9i3.pp307-317

Yanti, N. F., \& Sumianto, S. (2021). Analisis faktor-faktor yang menghambat minat belajar dimasa pandemi COVID-19 pada siswa SDN 8 Salo [Analysis of factors that hinder interest in learning during the COVID-19 pandemic in SDN 8 Salo students]. Jurnal Pendidikan Tambusai, 5(1), 608-614. https://doi.org/10.21067/jbpd.v5i2.5754

Yilmaz, A., \& Kostur, M. (2021). Rethinking principles of school mathematics during the COVID-19 pandemic: A multiple-case study on higher education courses related to teaching mathematics. International Electronic Journal of Mathematics Education, 16(3), Article em0653. https://doi.org/10.29333/iejme/11103

Yohannes, Y., Juandi, D., Diana, N., \& Sukma, Y. (2021). Mathematics teachers' difficulties in implementing online learning during the COVID-19 pandemic. Journal of Hunan University Natural Sciences, 48(5), 87-98.

Yuliana, R. (2021). Pengaruh pembelajaran daring dan fasilitas penunjang terhadap kinerja guru dan hasil belajar siswa [The influence of online learning and supporting facilities on teacher performance and student learning outcomes]. Jurnal Lipnas, 3(2), 1-18.

Yunitasari, R., \& Hanifah, U. (2020). Pengaruh pembelajaran daring terhadap minat belajar siswa pada masa COVID-19 [The effect of online learning on students' interest in learning during the COVID-19 period]. Edukatif: Jurnal Ilmu Pendidikan, 2(3), 232-243. https://doi.org/10.31004/edukatif.v2i3.142 